\title{
The mating system and genetic structure in a disjunct population of the seaside goldenrod Solidago sempervirens L. (Asteraceae)
}

\author{
David J. Innes* and \\ Luise A. Hermanutz**
}

Department of Biological Sciences, University of

Windsor, Windsor, Ontario, Canada, N9B 3 P4.

Three polymorphic enzyme loci were used to study mating system and genetic structure in a disjunct population of the seaside goldenrod, Solidago sempervirens, growing near Windsor, Ontario to determine if self-fertility played a role in the initial colonization of this area. Observations on genotypic variation in the adult populations and the analysis of progeny arrays showed no evidence for inbreeding with estimates of outcrossing rate not significantly different from $t=1.00$ for both the Windsor population and a population from the main distribution of the species. Colonization of southern Ontario by $S$. sempervirens probably involved either a single colonization event consisting of several individuals with different self-incompatibility genotypes or a number of separate colonizing episodes.

\section{INTRODUCTION}

Plants exhibit a diversity of mating systems ranging from self-incompatible obligate outcrossers to selfcompatible species with various levels of selffertilization. Theoretical and empirical observations have attempted to examine the ecological and evolutionary processes which may favour one mating system over the other (Jain, 1976; Lloyd, 1980; Lande and Schemske, 1985; Schemske and Lande, 1985). Self-compatibility has often been cited as an advantage for colonizing species because a single individual can establish a new population (Baker, 1955, 1967; Antonovics, 1968). Successful colonization of a new area by obligate sexually reproducing self-incompatible species would have to depend on several colonizing individuals with different self-incompatibility genotypes.

However, the colonization process itself may facilitate the breakdown of self-incompatibility in a self-incompatible species. For example, many self-incompatible species show some capacity for setting a few seeds by self-pollination (Davies and Young, 1966; Thompson and Taylor, 1966;

\footnotetext{
* Present Address: Department of Biology, Memorial University of Newfoundland, St. John's, Newfoundland, Canada, A1B 3X9.

** Present Address: Department of Plant Sciences, University of Western Ontario, London, Ontario, Canada, N6A 5B7.
}

Antonovics, 1968; Lefebvre, 1970; Ronald and Ascher, 1975; de Nettancourt, 1977; Wu and Jain, 1980; Kress, 1983). The few seeds set by a single colonizing individual may lead to a breakdown in the self-incompatible mechanism, providing that self-fertility is heritable and inbreeding depression does not prevent the establishment of seedlings from self-pollinated seeds (Schemske, 1983; Schoen, 1983). Inbreeding as a result of populations being founded by a few self-incompatible individuals may also contribute to the breakdown of self-incompatibility. Outcrossing species with disjunct populations showing a higher frequency of selfing suggest that there may have been a breakdown of self-incompatibility during the colonization process (Lloyd, 1980). For example, selfincompatible species colonizing and adapting to contaminated mine soils exhibited a higher rate of self-fertility compared to non-tolerant populations of each species (Antonovics, 1968; Lefebvre, 1970). Selfing in the tolerant population is an effective barrier to gene flow from adjacent non-tolerant populations (Antonovics, 1968), but self-fertility may have evolved during the colonization of contaminated soils by a small number of founding individuals (Lefebvre, 1970). Self-fertility would ensure some seed set in the absence or low probability of cross pollination during the early stages of colonization (Baker, 1955; 1967). The high frequency of self-fertility in some peripheral popu- 
lations of strawberry clover (Trifolium fragiferum) also may have evolved under conditions of low probability of cross pollination (Davies and Young, 1966). Observations on the inheritance of self-fertility in these and other species provide evidence for the evolution of self-compatibility under conditions which limit cross pollination such as low plant density and the lack of pollinators (Davies and Young, 1966; Thompson and Taylor, 1966; Antonovics, 1968; Ronald and Ascher, 1975). Colonization events may also be a factor contributing to a breakdown in the incompatibility mechanism of heteromorphic incompatible species (Glover and Barrett, 1986; Barrett, 1979).

Genetic variation and mating system have been examined in a disjunct population of $S$. sempervirens L. growing near Windsor, Ontario to determine if self-fertility played a role in the initial colonization of this area. Estimates of outcrossing rates in naturally pollinated progeny arrays were used to compare the level of selfing in the Windsor population with a population sampled from the main distribution of this species on the east coast of North America.

\section{MATERIALS AND METHODS}

The seaside goldenrod, $S$. sempervirens, grows on saline soils along the Gulf of Mexico and the Atlantic coast as far north as the Gulf of St. Lawrence (Gleason and Cronquist, 1963; Boettcher, 1980; Cartica and Quinn, 1980, 1982). A large amount of morphological and floweringtime variation has been observed among populations (Goodwin, 1944; Boettcher, 1980). Two varieties have been recognized, $S$. sempervirens var. sempervirens (northern form) and $S$. sempervirens var. mexicana (southern form) (Gleason and Cronquist, 1963; Boettcher, 1980). Chromosome counts show $2 n=18$ with no variation observed across the species range (Boettcher, 1980; Semple et al., 1984).

Solidago sempervirens is a herbaceous perennial species forming distinct genets consisting of many ramets. Similar to other species of Solidago (Gross and Werner, 1983), S. sempervirens is selfincompatible (Goodwin, 1937; 1944) relying on honeybees (Apis mellifera) to move pollen between individuals (Hermanutz, personal observation). In southern Ontario this species flowers from about mid September to mid October. Groups of flowering heads (capitula) are determinate, blooming sequentially from tip to base within an individual, so that early and late blooming flowering heads can be distinguished. Later blooming flowers within genets and later blooming genets may experience pollinator limitations due to adverse weather conditions and frost, resulting in a lower seed set (Hermanutz, unpublished).

Isolated populations of $S$. sempervirens occur near Windsor, Ontario over 1000 kilometers from the main distribution of this species along the Atlantic coast (fig. 1). The Windsor populations consist of a few areas with several hundred individuals growing on saline soils associated with brine wells and salt-mine activity (Catling and MacKay, 1980). Brine wells have been in continuous operation in this area since about 1893 (Sanford, 1957). Single plants are also found growing in road-side ditches several kilometers from areas of high density. In addition to road-side isolates, five individuals were found growing at the HB site on the shore of Lake Erie (fig. 1). $S$. sempervirens was discovered in southern Ontario in 1974 (Catling and McKay, 1980); the age of origin of these individuals is presently unknown. A disjunct population of this species has also been recorded from the Chicago area (Swink, 1974).

Leaf samples from individuals of $S$. sempervirens were collected in the fall of 1984 from three populations (WS, TV, RC) near Windsor, as well as from isolated individuals (fig. 1). Individual genets from WS, TV and RC were sampled at $1 \mathrm{~m}$ intervals along transects through each population, and each sampled individual in the RC population was tagged for later sampling of mature seeds. Leaf samples were returned to the laboratory for electrophoresis within one day of collection. A sample of seeds was obtained from individuals in a population near the middle of the distribution of this species (fig. 1) on the south shore of Long Island (Smith Point, New York).

Mature seeds were collected in late fall from 20 marked individuals separated by about $5 \mathrm{~m}$ intervals along transects in the $\mathrm{RC}$ population. Five seeds were randomly sampled from two early and two late-blooming flower heads for a total of 20 seeds per individual. This was to determine if there were any differences in outcrossing rate between early and late blooming flower heads. Five seeds from four flower heads were sampled from 26 individuals in the Long Island (LI) population. In this population flower heads were sampled at random without respect to flowering time. Seeds were stored at $5^{\circ} \mathrm{C}$ prior to electrophoresis.

Leaf tissue and individual seeds were prepared for electrophoresis by grinding with a small amount of PVPP (polyvinylpolpyrrolidone) and a few drops of buffer $(10 \mathrm{ml} 0 \cdot 1 \mathrm{M}$ Tris- $\mathrm{HCl}, p \mathrm{H} 8 \cdot 0$, 


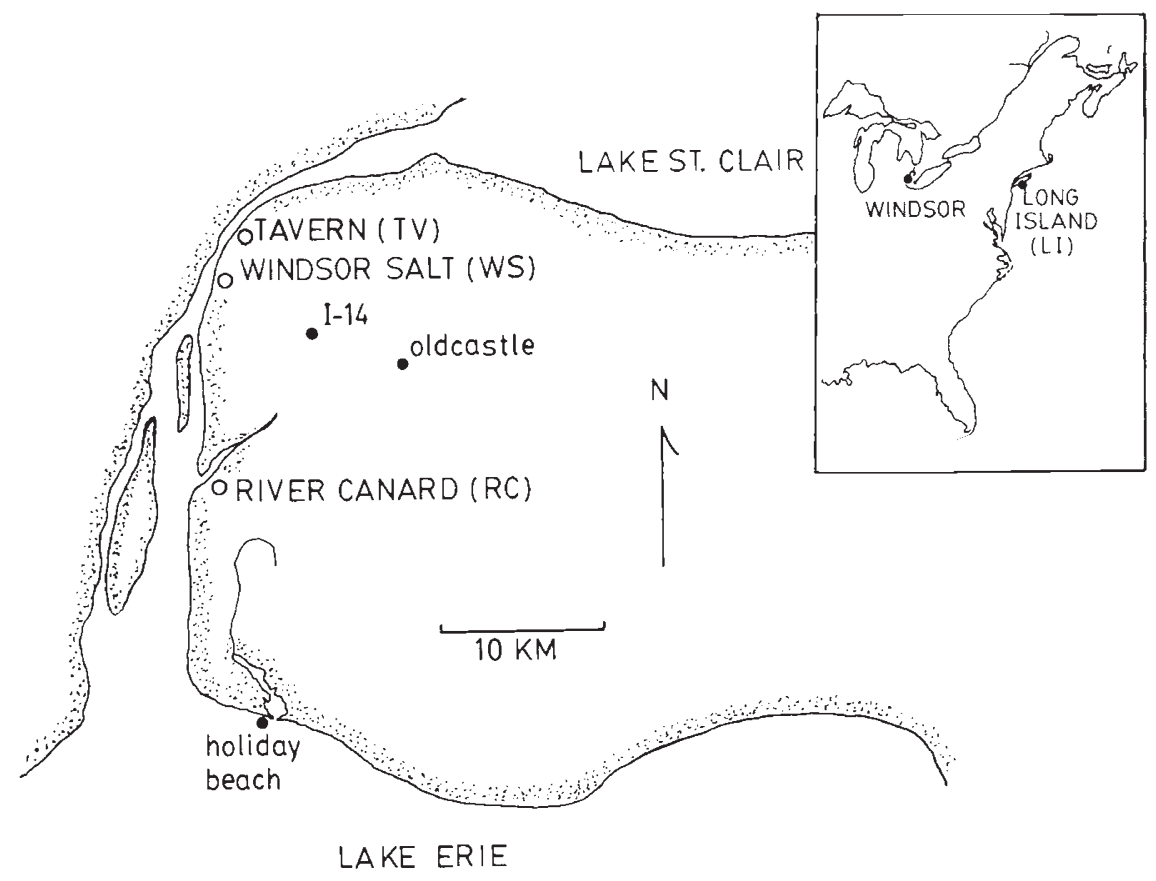

Figure 1 Map of the populations sampled near Windsor, Ontario and Long Island, New York (inset). Windsor populations: Tavern (TV), Windsor Salt (WS), River Canard (RC). Single isolates at I-14 and Oldcastle and five individuals at Holiday Beach (HB).

2 drops of mercaptoethanol) to form a slurry. Samples were kept on ice during grinding and were analyzed electophoretically for three enzymes; PGI (phosphoglucose isomerase), PGM (phosphoglucomutase) and ADH (alcohol dehydrogenase). These enzymes were chosen because they were reliably resolved and polymorphic. PGI and PGM were stained on cellulose acetate gels (Helena Laboratories, Beaumont, Texas) using a Tris-glycine buffer ( $3 \mathrm{~g} / 1$ Trizma base, $14.4 \mathrm{~g} / 1$ glycine). ADH was stained on a lithium borate starch gel (Selander et al., 1969). Enzyme stains followed standard procedures (Harris and Hopkinson, 1976).

Leaf tissue was used to determine each maternal genotype in the RC population and seeds from each maternal individual used to determine progeny genotype arrays. The same three loci were expressed in both the leaf and seed tissue. Maternal genotypes of the 26 individuals sampled from the LI population were inferred from progeny genotype arrays using the method of Brown et al. (1975). Segregation patterns in progeny arrays and results from crosses confirmed the genetic basis of the enzyme variation. Single-locus estimates of outcrossing rate $(t)$ and pollen gene frequency were calculated as outlined in Brown et al. (1975). Multilocus estimates of outcrossing rate used the method of Green et al. (1980). Similar estimates were obtained using a program developed by $\mathrm{K}$. Ritland (Ritland and Jain, 1981).

\section{RESULTS}

\section{(i) Genetic structure}

The Long Island and Windsor populations shared the same two alleles at Pgi, Pgm and Adh. However, seeds from the Long Island sample had been stored for several months and $A D H$ activity was too weak to score in all individuals. Estimates of allele frequency and inbreeding coefficients (F) for Pgi, Pgm and $A d h$ in samples of the adult populations are presented in table 1. All samples were consistent with Hardy-Weinberg genotype proportions at the three loci, with inbreeding coefficients not significantly different from zero (table 1). Significant heterogeneity in allele frequency for all three loci was found among the population samples using heterogeneity $G$ tests on the genotype frequencies (Sokal and Rohlf, 1981). An overlapping pattern of differentiation was observed for Pgi (table 1), with WS and LI showing the largest frequency difference for the $\mathrm{S}$ allele $(0.66$ and 0.85 , respectively). Differentiation at the Pgm locus showed the highest frequency for the 
Table 1 Adult allele frequencies and inbreeding coefficients $(F)$ for four populations of Solidago sempervirens. Allele frequency variation among populations not significantly different $(P>0.05)$ if followed by the same letter. Standard errors in parentheses

\begin{tabular}{|c|c|c|c|c|c|c|c|}
\hline \multirow[b]{2}{*}{ Population } & \multirow[b]{2}{*}{$N$} & \multicolumn{3}{|c|}{ Freq. of $S$ allele (S.E.) } & \multicolumn{3}{|c|}{$F$ (S.E.) } \\
\hline & & $P g i$ & Pgm & $A d h$ & $P g i$ & $P g m$ & $A d h$ \\
\hline $\mathrm{RC}$ & 96 & $\begin{array}{c}0.75 a b \\
(0.03)\end{array}$ & $\begin{array}{c}0.83 a \\
(0.03)\end{array}$ & $\begin{array}{c}0.77 a \\
(0.03)\end{array}$ & $\begin{array}{c}0.06 \\
(0 \cdot 11)\end{array}$ & $\begin{array}{c}-0.05 \\
(0.11)\end{array}$ & $\begin{array}{c}-0.12 \\
(0 \cdot 11)\end{array}$ \\
\hline WS & 96 & $\begin{array}{c}0.66 a \\
(0.03)\end{array}$ & $\begin{array}{l}0.66 b \\
(0.03\end{array}$ & $\begin{array}{c}0.95 b \\
(0.02)\end{array}$ & $\begin{array}{c}0.001 \\
(0.10)\end{array}$ & $\begin{array}{c}-0.06 \\
(0.10)\end{array}$ & $\begin{array}{c}-0 \cdot 10 \\
(0 \cdot 16)\end{array}$ \\
\hline TV & 42 & $\begin{array}{l}0.82 a b \\
(0.04)\end{array}$ & $\begin{array}{c}0.74 a \\
(0.05)\end{array}$ & $\begin{array}{c}0.95 b \\
(0.02)\end{array}$ & $\begin{array}{c}-0.21 \\
(0.18)\end{array}$ & $\begin{array}{c}-0 \cdot 11 \\
(0 \cdot 16)\end{array}$ & $\begin{array}{r}-0.003 \\
(0.16)\end{array}$ \\
\hline LI & 26 & $\begin{array}{c}0.85 b \\
(0.05)\end{array}$ & $\begin{array}{c}0.27 c \\
(0.06)\end{array}$ & - & $\begin{array}{c}0.11 \\
(0.23)\end{array}$ & $\begin{array}{c}0.22 \\
(0.21)\end{array}$ & - \\
\hline
\end{tabular}

$\mathrm{S}$ allele in the samples from RC and TV, an intermediate frequency at WS and the lowest frequency in the sample from the LI population (table 1). Frequency of the $A d h \mathrm{~S}$ allele was significantly lower in the sample from RC compared to WS and TV (table 1).

The level of genetic substructuring within populations was determined by examining the pattern of genetic variation along transects and differentiation between separate transects within populations. Substructuring can severely bias outcrossing rate estimates in the direction of increased selfing (Ennos and Clegg, 1982). The distribution of genotypes along transects was known for individuals sampled from the four populations. Using a runs test (Sokal and Rohlf, 1981), the two common genotypes at each locus were found to be distributed at random along transects in each of the four populations, confirming the occurrence of different genets when individuals were sampled at 1 metre intervals and the absence of genetic substructuring. Individuals in the RC and WS populations were collected along four and three transects, respectively. Only the $A d h$ locus showed significant heterogeneity $(G=16.4, P<0.01)$ in genotypic frequency among the transects in the $\mathrm{RC}$ population.

Non-random associations (gametic disequilibria) among the three loci were tested (Hedrick et al., 1978) in the sample of adults from WS, TV and RC. Only Pgi and Pgm in the WS sample showed some evidence for any non-random association (table 2). Disequilibrium was not tested in the LI sample due to the small number of individuals.

\section{(ii) Outcrossing rate}

Single locus estimates of outcrossing rate $(t)$ were calculated for early and late blooming flowering heads in the RC population as well as a combined estimate for the population. These estimates were compared to single locus estimates for the LI population. Except for the estimate for early blooming flowers in the RC population using the $A d h$ locus, all single-locus estimates showed no significant differences from $t=1.0$ (table 3 ), suggesting that pollinator limitations did not affect outcrossing rate. The decreased "apparent" outcrossing rate for the $A d h$ locus could be due to genetic substructuring since heterogeneity in $A d h$ genotype frequency was found among transects in the RC population. However, if this were the only cause for a decrease in apparent outcrossing rate at this locus then the outcrossing rate estimate using progeny from late blooming flowers from the same maternal parent should also show a decreased outcrossing rate. Alternatively, early blooming flowers may be receiving a non-random sample of the pollen pool with respect to the $A d h$ locus due to non-random pollinator behaviour or temporal differences in flowering time between $A d h$ genotypes.

Multilocus estimates of outcrossing rate also showed no significant differences from $t=1 \cdot 0$ for all samples (table 3 ). These results show no evidence for differences in outcrossing rate

Table 2 Gametic disequilibrium $(D)$ estimates among three allozyme loci in three populations of $S$. sempervirens. Test for $D=0$

\begin{tabular}{llll}
\hline & \multicolumn{3}{l}{ Population } \\
\cline { 2 - 4 } Loci & RC & WS & TV \\
\hline Pgi-Pgm & -0.021 & $-0.052^{*}$ & -0.019 \\
Pgi-Adh & -0.025 & 0.012 & -0.007 \\
Pgm-Adh & -0.038 & -0.018 & -0.013 \\
\hline
\end{tabular}

${ }^{*} P<0.05$. 
Table 3 Single locus and multilocus estimates of outcrossing rate $t$ (SE) for early and late blooming flower heads in the RC population and combined estimates for the RC population compared with estimates for the LI population

\begin{tabular}{|c|c|c|c|c|c|c|}
\hline & \multirow{2}{*}{$\begin{array}{l}\text { Number of } \\
\text { Families }\end{array}$} & \multirow{2}{*}{$\begin{array}{l}\text { Total number } \\
\text { of progeny }\end{array}$} & \multicolumn{3}{|c|}{ Single Locus } & \multirow[b]{2}{*}{ Multilocus } \\
\hline & & & $P g i$ & $P g m$ & Adh & \\
\hline RC early & 20 & 197 & $\begin{array}{c}0.93 \\
(0.11)\end{array}$ & $\begin{array}{c}0.93 \\
(0.13)\end{array}$ & $\begin{array}{c}0 \cdot 70^{*} \\
(0 \cdot 12)\end{array}$ & $\begin{array}{c}0.95 \\
(0.08)\end{array}$ \\
\hline RC late & 19 & 174 & $\begin{array}{c}0.99 \\
(0.13)\end{array}$ & $\begin{array}{c}0.84 \\
(0.17)\end{array}$ & $\begin{array}{c}1.03 \\
(0.08)\end{array}$ & $\begin{array}{l}1.05 \\
(0.09)\end{array}$ \\
\hline RC pop. & 19 & 362 & $\begin{array}{c}0.97 \\
(0.08)\end{array}$ & $\begin{array}{c}0.88 \\
(0.11)\end{array}$ & $\begin{array}{c}0.96 \\
(0.07)\end{array}$ & $\begin{array}{c}0.97 \\
(0.05)\end{array}$ \\
\hline LI pop. & 26 & 476 & $\begin{array}{c}0.87 \\
(0.08)\end{array}$ & $\begin{array}{c}0.94 \\
(0.05)\end{array}$ & - & $\begin{array}{c}0.90 \\
(0.05)\end{array}$ \\
\hline
\end{tabular}

$* t$ significantly different from $1.0(P<0.05)$

between early and late blooming flowers in the RC population. Furthermore, neither the RC nor the LI populations show any evidence for a significant level of self-pollination. The possibility of genetic heterogeneity in the pollen pool was tested by examining the heterogeneity in proportion of heterozygous progeny among maternal plants homozygous for each locus (Brown et al., 1975). According to the mixed-mating model (Clegg, 1980), each maternal plant is expected to receive a random sample of pollen from the pollen pool. Therefore, maternal plants homozygous for a locus should, on average, show the same proportion of heterozygous progeny. Tests for heterogeneity in the proportion of heterozygous progeny showed no heterogeneity among the tested families except for the Pgm locus in the RC population (table 4). However, if this is a result of non-random sampling of the pollen pool with respect to this locus it does not appear to be sufficient to affect the estimate of outcrossing rate (table 3 ). Homogeneity of the proportion of heterozygotes with respect to the $A d h$ locus suggests that non-random sampling of the pollen pool may not be responsible for the observed deviation of outcrossing rate from $t=1 \cdot 0$

Table 4 Tests for heterogeneity in proportion of heterozygous progeny from maternal genotypes homozygous at individual allozyme loci

\begin{tabular}{lllrl}
\hline Population & $\begin{array}{l}\text { Maternal } \\
\text { genotype }\end{array}$ & $\begin{array}{l}\text { Number of } \\
\text { families }\end{array}$ & \multicolumn{1}{c}{$G$} & $P$ \\
\hline RC & PGI SS & 11 & $7 \cdot 6$ & $\mathrm{~ns}$ \\
RC & PGM SS & 11 & $18 \cdot 4$ & $<0.05$ \\
RC & ADH SS & 10 & $9 \cdot 3$ & $\mathrm{~ns}$ \\
LI & PGI SS & 19 & $17 \cdot 6$ & $\mathrm{~ns}$ \\
LI & PGM FF & 15 & $13 \cdot 2$ & $\mathrm{~ns}$ \\
LI & PGM SS & 3 & $0 \cdot 2$ & $\mathrm{~ns}$ \\
\hline
\end{tabular}

in the earlier blooming flowers in the RC population.

Pollen allele frequencies, estimated from early or late progeny arrays, were similar to the corresponding adult allele frequencies (table 5). However, in the RC population, the frequency of the $A d h \mathrm{~S}$ allele was estimated to be significantly higher for the pollen pool (estimated from the late progeny array and the combined early and late progeny array) compared with the allele frequency estimated from the adult population (table 5).

\section{(iii) Isolates}

Single genets of $S$. sempervirens were observed growing in road-side ditches. Seed set was examined in two isolates separated from each other

Table 5 Adult and pollen allele (S) frequency estimates (S.E.) for three allozyme loci. Pollen frequency estimates from progeny arrays (see table 3 ) and adult frequency estimates from table 1. Estimates for pollen allele frequency from progeny arrays from early and late blooming flowers in the $\mathrm{RC}$ population and combined estimates for the RC population. Pollen and adult allele frequencies tested ( $t$ test) for significant differences

\begin{tabular}{|c|c|c|c|c|c|c|}
\hline & \multicolumn{2}{|l|}{$P g i$} & \multicolumn{2}{|l|}{$P g m$} & \multicolumn{2}{|l|}{ Adh } \\
\hline & Pollen & Adult & Pollen & Adult & Pollen & Adult \\
\hline RC early & $\begin{array}{c}0.80 \\
(0.03)\end{array}$ & $\begin{array}{c}0.75 \\
(0.03)\end{array}$ & $\begin{array}{c}0.87 \\
(0.03)\end{array}$ & $\begin{array}{c}0.83 \\
(0.03)\end{array}$ & $\begin{array}{c}0.82 \\
(0.04)\end{array}$ & $\begin{array}{c}0.77 \\
(0.03)\end{array}$ \\
\hline RC late & $\begin{array}{c}0.70 \\
(0.04)\end{array}$ & $\begin{array}{c}0.75 \\
(0.03)\end{array}$ & $\begin{array}{c}0.79 \\
(0.05)\end{array}$ & $\begin{array}{c}0.83 \\
(0.03)\end{array}$ & $\begin{array}{c}0.89 \\
(0.03)\end{array}$ & $\begin{array}{c}0.77^{*} \\
(0.03)\end{array}$ \\
\hline RC pop. & $\begin{array}{c}0.75 \\
(0.03)\end{array}$ & $\begin{array}{c}0.75 \\
(0.03)\end{array}$ & $\begin{array}{c}0.84 \\
(0.02)\end{array}$ & $\begin{array}{c}0.83 \\
(0.03)\end{array}$ & $\begin{array}{c}0.86 \\
(0.02)\end{array}$ & $\begin{array}{c}0.77^{*} \\
(0.03)\end{array}$ \\
\hline LI pop. & $\begin{array}{c}0.84 \\
(0.02)\end{array}$ & $\begin{array}{c}0.85 \\
(0.05)\end{array}$ & $\begin{array}{c}0.18 \\
(0.02)\end{array}$ & $\begin{array}{c}0.27 \\
(0.06)\end{array}$ & - & - \\
\hline
\end{tabular}

$* P<0.05$ 
by about 6 kilometres and from the nearest population by more than 6 kilometres (fig. 1). Seed set in the Oldcastle isolate was 2 per cent $(228$ florets examined) and 4 per cent (1602 florets examined) in the I-14 isolate. The three-locus genotype of the I-14 isolate was SS-SF-SS (Pgi, Pgm, Adh) and two of the 72 seeds were the result of outcrossing since both seeds were SF heterozygotes at Pgi and $A d h$. A possible source for this outcross pollen was an isolate $1 \mathrm{~km}$ away with a three-locus genotype of SF-SS-SF. $S$. sempervirens is the only conspicuously flowering species at this time of year and may explain long-distance pollinator movement between isolated individuals. The remaining 70 seeds were SS homozygotes at $P g i$ and $A d h$ with $P g m$ showing no significant $\left(\chi^{2}=2 \cdot 91, P>\right.$ $0.05)$ deviation from a $1: 2: 1$ segregation of the three genotypes. These observations suggest that the 70 seeds were the result of self-pollination because no individuals with the same three-locus genotypes as the I-14 isolate were detected within a 1-2 kilometre radius. Of the five isolated individuals found at $\mathrm{HB}$ (fig. 1), four had different three-locus genotypes. High seed set was found in these isolates similar to the individuals from the larger RC and WS populations. Seven of the ten seeds sampled from one individual were detected to be produced by outcrossing.

\section{DISCUSSION}

No evidence was found for a higher level of selfing and inbreeding in a disjunct population of $S$. sempervirens growing near Windsor, Ontario compared to a native population from Long Island, New York. Both populations showed outcrossing rates not significantly different from $t=1 \cdot 0$. Colonization of southern Ontario by $S$. sempervirens probably involved either a single colonizing event consisting of more than one individual or a number of separate colonizing episodes. No information is available as to the origin of the individuals founding the Windsor populations. Since the $S$. sempervirens populations near Windsor are adjacent to the Detroit river one possible route from the east coast would be for the wind dispersed seeds to be carried by ships travelling through the St. Lawrence Seaway and up the Detroit river.

Although there were some gene frequency differences, the Long Island and Windsor populations shared the same alleles for three enzyme loci. The genetic relationship between the Windsor populations and populations along the east coast cannot be evaluated without additional information on gene frequency variation along the east coast. However, there were some morphological differences betweeen individuals from the two areas. Comparisons between individuals grown from seed under common greenhouse conditions showed that the Long Island individuals had wider leaves, flowered later, produced flower heads with more flowers and set heavier seeds (Hermanutz and Innes, in preparation). These differences suggest that the $S$. sempervirens near Windsor is similar to the more southern var. mexicana $(\mathrm{L}$.) Fern. while the Long Island population resembles the more northern var. sempervirens (Goodwin, 1944; Gleason and Cronquist, 1963; Boettcher, 1980). A more detailed genetic and morphological survey of $S$. sempervirens along the east coast should be able to determine the affinity of the Windsor populations to populations along the Atlantic coast.

Preliminary pollination experiments under greenhouse conditions attempted to determine seed set in $S$. sempervirens after self-pollination of individuals collected from the Windsor populations. The average proportion seed set per flower head was significantly higher for the outcrossed treatment $(0.85 \pm 0.03$ S.E., $N=34$ heads $)$ compared to self-pollinations $(0 \cdot 25 \pm 0 \cdot 03, N=36)$ or untouched controls $(0 \cdot 26 \pm 0 \cdot 04, N=36)$. These results suggest that a 25 per cent seed set may be possible after self-pollination. However, this seed set appeared to have been the result of contaminating cross pollen since space limitations prevented a large distance separating each plant. Cross pollination was determined by comparing the maternal and progeny genotypes for these seeds. Of the 170 seeds examined a minimum of 44 per cent outcrossing was detected (i.e., heterozygous progeny from homozygous mothers). Although the selfed treatment showed a reduced seed set compared to the outcross treatment, additional experiments are required in order to assess the level of self-fertility in the Windsor $S$. sempervirens.

Even though $S$. sempervirens appears to be self-incompatible, a few seeds were observed to be set by single individuals isolated from the main population. It is likely that these seeds were set through self-pollination. A small proportion of seeds set by isolated individuals can still result in many seeds because of the large number of flowers produced by the perennial plants. Although seeds from one isolate were germinated and grown into flowering plants under greenhouse conditions, no new seedlings were observed growing near the isolated individuals. Inbreeding depression, expressed under natural conditions, may be pre- 
venting the establishment of these inbred seedlings in nature (Schemske, 1983; Schoen, 1983).

The expression of inbreeding depression following self-fertilization may be one factor preventing the evolution of selfing in predominantly outcrossing species (Schemske and Lande, 1985). In the absence of inbreeding depression a gene promoting selfing in addition to outcrossing would rapidly become fixed (Wells, 1979). This model applies to large outcrossing populations in which a large number of recessive deleterious mutations have accumulated. Population bottlenecks, such as during the colonization of new areas, may reduce inbreeding depression so that selfing becomes advantageous (Lande and Schemske, 1985). Some evidence for this process was found in a study comparing outcrossing rates among populations of Gilia achilleifolia (Schoen, 1982a). The more northerly populations, which were probably founded by a small number of individuals (Schoen, 1982b), showed decreased protandry accompanied by a higher rate of selfing. Selection may have played a role in modifying the breeding system since some of the observed variation in degree of protandry (and as a consequence selfing rate) appeared to be under genetic control.

The evolution of self-fertilization in self-incompatible species requires a breakdown in the selfincompatibility mechanism in addition to overcoming the effects of inbreeding depression. Several examples demonstrate that self-incompatibility and inbreeding depression have not proven to be insurmountable barriers to the evolution of self-fertility (Davies and Young, 1966; Thompson and Taylor, 1966; Antonovics, 1968; Lefebvre, 1970; Ronald and Ascher, 1975; Rick et al., 1979). The occurrence of self-fertility in some of these species appears to be associated with colonizing situations where self-fertility would have an advantage over outcrossing in ensuring some seed set (Antonovics, 1968). However, the ease of transition from self-sterility to self-fertility varies among species and even among different populations of the same species. For example, both Anthoxanthum odoratum (Antonovics, 1968; Wu and Jain, 1980) and Trifolium fragiferum (Davies and Young, 1966) consist of populations which show some self-fertility as well as populations which are highly self-sterile. The evolution of self-fertility in some populations of these species may have been due to a rare combination of genetic and environmental factors which may only occur with a frequency on the order of mutation rates ( Wu and Jain, 1980). Chance events may have also been responsible for the evolution of a self-compatible species from self-incompatible Stephanomeria exigua ssp. coronaria (Gottlieb, 1973).

Although the Ontario populations of $S$. sempervirens were probably established by a small number of individuals, the initial inbreeding and the expected reduction in inbreeding depression did not result in the evolution of self-fertility. Furthermore, the spread of this species around the local area has not been facilitated by any increase in the rate of selfing. Single, isolated individuals do not appear capable of establishing new colonizing populations by producing a small number of seeds through self-pollination. These observations would suggest that the initial colonizing individuals establishing the Ontario population did not pass through a stage of self-fertility followed by a reversion to self-incompatibility. Additional observations are needed on the rate of production of selfed seeds and the fitness of selfed progeny under natural conditions in order to understand the factors preventing the evolution of self-fertility in this species. Attempts to select for self-compatibility and generate a reduction in inbreeding depression would also provide information on the potential for shifting the breeding system from obligate outcrossing to selfing. The ability to evolve selfcompatibility and a selfing mating system may vary considerably among self-incompatible species. It would be instructive to know if the inability to evolve selfing in some species is due to difficulties in overcoming the self-incompatibility mechanism or the expression of inbreeding depression in selfed progeny.

Acknowledgements This research was supported by a University of Windsor Research Grant. We wish to thank P. D. N. Hebert and I. M. Weis for laboratory space and assistance from their NSERC grants. A. Dicks was kind enough to provide greenhouse space and maintained the plants. D. J. I. was supported by a NSERC Postdoctoral Fellowship. We thank J. D. Thomson for collecting the sample from Long Island, R. J. Bayer, N. C. Ellstrand, G. S. Ringuis and D. J. Schoen for comments and $\mathrm{K}$. Ritland for his outcrossing rate program.

\section{REFERENCES}

ANTONOVICS, J. 1968. Evolution in closely adjacent plant populations V. Evolution of self-fertility. Heredity, 23, 219238.

BAKER, H. G. 1955. Self-compatibility and establishment after "long-distance" dispersal. Evolution, 9, 347-349.

BAKER, H. G. 1967. Support for Baker's Law-as a rule. Evolution, 21, 853-856.

BARRETT, S. C. H. 1979. The evolutionary breakdown of tristyly in Eichhornia crassipes (Mart.) Solms. (Water Hyacinth). Evolution, 33, 499-510. 
Boettcher, R. C. 1980. A Systematic Study of the Solidago sempervirens L. (Compositae) Complex. MSc Thesis, Louisiana State University, Baton Rouge, U.S.A.

BROWN, A. H. D., MATHESON, A. C. AND ELDRIGE, K. G. 1975. Estimation of the mating system of Eucalyptus obliqua L'Herit. by using allozyme polymorphisms. Aust. J. Bio. Sci., 23, 931-949.

CARTICA, R. J. AND QUINN, J. A. 1980. Responses of populations of Solidago sempervirens (Compositae) to salt spray across a barrier beach. Am. J. Bot., 67, 1236-1242.

CARTICA, R. J. AND QUINN, J. A. 1982. Resource allocation and fecundity of populations of Solidago sempervirens along a coastal dune gradient. Bull. Torrey bot. Club, 109, 299-305.

CATLING, P. M. AND MACKAY, S. M. 1980. Halophytic plants in Southern Ontario. Can. Field Nat., 94, 248-258.

CLEGG, M. 1980. Measuring plant mating systems. Bioscience, 30, $814-818$.

DAVIES, W. E. AND YOUNG, N. R. 1966. Self-fertility in Trifolium fragiferum. Heredity, 21, 615-624.

ENNOS, R. A. AND CLEGG, M. T. 1982. Effect of population substructuring on estimates of outcrossing rate in plant populations. Heredity, 48, 283-292.

GLEASON, H. A. AND CRONQUIST, A. 1963. Manual of Vascular Plants of Northeastern United States and Adjacent Canada. D. Van Nostrand Co., Inc., Princeton, N.J.

GLOVER, D. E. AND BARRETT, S. C. H. 1986. Variation in the mating system of Eichhornia paniculata (Spreng.) Solms. (Pontederiaceae). Evolution, 40, 1122-1131.

GOODWIN, R. H. 1937. The cytogenetics of two species of Solidago and its bearing on their polymorphism in nature. Am. J. Bot., 24, 425-432.

GOODWIN, R. H. 1944. The inheritance of flowering time in a short-day species, Solidago sempervirens L. Genetics, 29, 503-519.

GOTTLIEB, L. D. 1973. Genetic differentiation, sympatric speciation, and the origin of a diploid species of Stephanomeria. Am. J. Bot., 60, 545-553.

GREEN, A. G., BROWN, A. H. D. AND ORAM, R. N. 1980. Determination of outcrossing rate in a breeding population of Lupinus albus L. (White Lupin). Z. Pflzucht., 84, 181-191.

GROSS, R. S. AND WERNER, P. A. 1983. Relationships among flowering phenology, insect visitors, and seed-set of individuals: experimental studies on four co-occurring species of goldenrod (Solidago: Compositae). Ecol. Monogr., 53, 95-117.

HARRIS, H. AND HOPKINSON, D. A. 1976. Handbook of Enzyme Electrophoresis in Human Genetics. North Holland, Amsterdam.

HEDRICK, P., JAIN, S. AND HOLDEN, L. 1978. Multilocus systems in evolution. Evol. Biol., 11, 101-184.

JAIN, S. 1976. The evolution of inbreeding in plants. Ann. Rev. Ecol. Syst., 7, 469-495.

KRESS, W. J. 1983. Self-incompatibility in Central American Heliconia. Evolution, 37, 735-744.

LANDE, R. AND SCHEMSKE, D. W. 1985. The evolution of self-fertilization and inbreeding depression in plants. I. Genetic models. Evolution, 39, 24-40.
LEFEBVRE, C. 1970. Self-fertility in maritime and zinc mine populations of Armeria maritima (Mill.) Willd. Evolution, 24, 571-577.

LLOYD, D. G. 1980. Demographic factors and mating patterns in angiosperms. In Solbrig, O. T. (ed.) Demography and Evolution in Plant Populations, Bot. Monogr., vol. 15, University of California Press, pp. 67-88.

NETTANCOURT D. DE. 1977. Incompatibility in Angiosperms. Springer-Verlag, Berlin.

RICK, C. M., FOBES, J. F. AND TANKSLEY, S. D. 1979. Evolution of mating systems in Lycopersicon hirsutum as deduced from genetic variation in electrophoretic and morphological characters. Pl. Syst. Evol. 132, 279-298.

RITLAND, K. AND JAIN, S. K. 1981. A model for the estimation of outcrossing rate and gene frequencies using $n$ independent loci. Heredity, 47, 25-52.

RONALD, W. G. AND ASCHER, P. D. 1975. Self compatibility in garden Chrysanthemum: Occurrence, inheritance and breeding potential. Theor. Appl. Genet, 46, 45-54.

SANFORD, B. V. 1957. Salt deposits at Ojibway, Ontario. In Goudge, M. F., Haw, V. A. and Hewitt, D. F. (eds) The Geology of Canadian Industrial Mineral Deposits, Can. Inst. Min. and Met., pp. 208-215.

SCHEMSKE, D. W. 1983. Breeding system and habitat effects on fitness components in three neotropical Costus (Zingiberaceae). Evolution, 37, 523-539.

SCHEMSKE, D. W. AND LANDE, R. 1985. The evolution of self-fertilization and inbreeding depression in plants. II. Emperical observations. Evolution, 39, 41-52.

SCHOEN, D. J. 1982a. The breeding system of Gilia achilleifolia: variation in floral characteristics and outcrossing rate. Evolution, 36, 352-360.

SCHOEN, D. J. $1982 b$. Genetic variation and the breeding system of Gilia achilleifolia. Evolution, 36, 361-370.

SCHOEN, D. J. 1983. Relative fitnesses of selfed and outcrossed progeny in Gilia achilleifolia (Polemoniaceae). Evolution, 37, 292-301.

SElANDER, R. K., YANG, S. Y. AND HUNT, W. G. 1969. Polymorphism in esterases and hemoglobin in wild populations of the house mouse (Mus musculus). Studies in Genetics V. Univ. Texas Publ., 6918, 271-338.

SEMPLE, J. C., RINGUIS, G. S., LEEDER, C. AND MORTON G. 1984. Chromosome numbers of goldenrods, Euthamia and Solidago (Compositae: Astereae). II. Additional counts with comments on cytogeography. Brittonia, 36, 280-292.

SOKAL, R. R. AND ROHLF, F. J. 1981. Biometry (2nd edn). W. H. Freeman and Co., San Francisco.

SWINK, F. 1974. Plants of the Chicago Region. 2nd edition. Morton Arboretum, Lisle.

THOMPSON, K. F. AND TAYLOR, J. P. 1966. The breakdown of self-incompatibility in cultivars of Brassica oleracea. Heredity, 21, 637-648.

WELLS, H. 1979. Self-fertilization: advantageous or deleterious? Evolution, 33, 252-255.

WU, L. AND JAIN, S. 1980. Self-fertility and seed set in natural populations of Anthoxanthum odoratum L. Bot. Gaz., 141, 300-304. 